\title{
PEMILIHAN INPUT MODEL ADAPTIVE FUZZY INFERENCE SYSTEM (ANFIS) BERBASIS LAGRANGE MULTIPLIER TEST DILENGKAPI GUI MATLAB (Aplikasi pada Data Harga Beras Kualitas Rendah di Indonesia Periode Januari 2013 - Februari 2019)
}

\author{
Khusnul Umi Fatimah ${ }^{1}$, Tarno ${ }^{2}$, Abdul Hoyyi ${ }^{3}$ \\ 1,2,3 Departemen Statistika FSM Universitas Diponegoro \\ Tarno.stat@gmail.com
}

\begin{abstract}
Adaptive Neuro Fuzzy Inference System (ANFIS) is a method that uses artificial neural networks to implement fuzzy inference systems. The optimum ANFIS model is influenced by the selection of inputs, number of membership and rules. In general, the selection of ANFIS input is based on Autoregressive (AR) unit as a result of ARIMA preprocessing. Thus it requires several assumptions. In this research, an alternative selection of ANFIS input based on Lagrange Multiplier Test (LM Test) is used to test hypothesis for the addition of one input. Preprocessing is conducted to obtain the value of partial autocorrelation against $\mathrm{Zt}$. The input lag variable which has the highest partial autocorrelation is the first input ANFIS. The next input selection is selected based on LM test for adding one variable. To test the performance of LM Test, an empirical study of two groups of generated data and low quality rice prices is conducted as a case study. Generating data with stationary and non-stationary criteria has a good performance because it has very good forecasting ability with MAPE out sample for each characteristic are $5.6785 \%$ and $9.4547 \%$. In the case study using LM Test, the selected input are $Z_{t-1}$ and $Z_{t-2}$ with the number of membership 2. The chosen model has very good forecasting ability with MAPE outsampel $6.4018 \%$.
\end{abstract}

Keywords : ANFIS, ANFIS Input, LM-Test, Low Quality Rice Prices, Forecasting

\section{PENDAHULUAN}

ANFIS merupakan metode yang menggunakan neural network untuk mengimplementasikan sistem inferensi fuzzy (Jang et al, 1997). ANFIS dapat memproses data tanpa asumsi dan dapat diterapkan untuk data yang memiliki hubungan nonlinier antar pengamatan (Cheng et al, 2012). Menurut Tarno et al (2018) model ANFIS yang optimal dipengaruhi oleh pemilihan input, banyaknya keanggotaan dan aturan. Beberapa penelitian peramalan berbagai kasus dengan metode ANFIS telah dilakukan diantaranya peramalan model ANFIS hybrid berbasis AR dan volatilitas oleh Chang et al (2011), peramalan jumlah penumpang kereta api kelas ekonomi kertajaya menggunakan ARIMA dan ANFIS oleh Andalita dan Irhamah (2015), pemodelan kecepatan angin rata-rata di Sumenep menggunakan mixture of ANFIS oleh Permai et al (2013). Beberapa penelitian tersebut, pemilihan variabel lag input berdasarkan pada Autoregressive (AR) unit dari hasil preprocessing model ARIMA. Preprocessing ARIMA memerlukan asumsi stasioneritas yang dalam beberapa karakteristik data sulit untuk terpenuhi. Berdasarkan argumen tersebut, dalam penelitian ini membahas tentang pemilihan input ANFIS berbasis Lagrange Multiplier Test (LM Test). 
Prosedur pemilihan input ANFIS berbasis LM Test dicobakan pada data simulasi yang dibangkitkan dari ARIMA stasioner dan ARIMA non-stasioner. Pada penelitian ini studi kasus yang diambil adalah data harga beras kualitas rendah pada penggilingan di Indonesia. Data studi kasus dicobakan karena berdasarkan data historis yang diperoleh dari Badan Pusat Statistik (BPS) harga beras kualitas rendah pada penggilingan di Indonesia mengalami fluktuasi dari tahun ke tahun. Pemilihan input berbasis LM Test dilengkapi dengan GUI Matlab untuk mempermudah pengguna.

\section{TINJAUAN PUSTAKA}

\subsection{Arsitektur Adaptive Neuro Fuzzy Inference System (ANFIS)}

Adaptive Neuro-Fuzzy Inference System (ANFIS) adalah penggabungan fuzzy inference system yang digambarkan dalam arsitektur jaringan syaraf. Sistem inferensi fuzzy yang digunakan adalah sistem inferensi fuzzy model Tagaki-Sugeno-Kang (TSK) orde satu dengan pertimbangan kesederhanaan dan kemudahan komputasi (Fatkhurrozi et all, 2012).

Menurut Jang et al (1997), jumlah hidden layer pada jaringan syaraf tiruan pada ANFIS disesuaikan dengan sistem fuzzy yaitu: fuzzyfikasi (lapisan-1), sistem inferensi fuzzy (lapisan-2 dan lapisan-3), defuzzyfikasi (lapisan-4) dan agregasi (lapisan-5). Secara umum, arsitektur ANFIS untuk pemodelan data runtun waktu dengan 2 variabel input $Z_{t-1}, Z_{t-2}$ dan satu variabel output $Z t$ dengan mengasumsikan aturan dasar Sugeno order satu sebagai berikut:

If $Z_{t-1}$ is $A_{11}$ and $Z_{t-2}$ is $A_{12}$ then $Z_{t}^{(1)}=p_{11} Z_{t-1}+p_{12} Z_{t-2}+p_{10}$;

If $Z_{t-1}$ is $A_{21}$ and $Z_{t-2}$ is $A_{22}$ then $Z_{t}^{(2)}=p_{21} Z_{t-1}+p_{22} Z_{t-2}+p_{20}$;

dengan,

$Z_{t-1}$ is $A_{11}$ and $Z_{t-2}$ is $A_{12}, Z_{t-1}$ is $A_{21}$ and $Z_{t-2}$ is $A_{22}$ merupakan bagian premis,

$Z_{t}^{(1)}=p_{11} Z_{t-1}+p_{12} Z_{t-2}+p_{10} \quad$ dan $\quad Z_{t}^{(2)}=p_{21} Z_{t-1}+p_{22} Z_{t-2}+p_{20}$ merupakan bagian konsekuen,

$p_{11}, p_{12}, p_{10}, p_{21}, p_{22}, p_{20}$ merupakan parameter linear atau konsekuen,

$A_{11}, A_{12}, A_{22}, A_{21}$ merupakan parameter nonlinear atau premis.

Jika firing strength (derajat pengaktifan) untuk $Z_{t}^{(1)}$ dan $Z_{t}^{(2)}$ adalah $w_{1}$ dan $w_{1}$ maka output Zt dapat dihitung sebagai berikut:

$Z_{t}=\frac{w_{1} z_{t}^{(1)}+w_{2} z_{t}^{(2)}}{w_{1}+w_{2}}$

Arsitektur dasar ANFIS terdiri dari lapisan-lapisan sebagai berikut:

1. Lapisan 1 (Fuzifikasi input)

Pada lapisan pertama terjadi proses fuzifikasi. Proses ini adalah untuk memetakan inputan data kedalam himpunan fuzzy. Tiap-tiap neuron i pada lapisan pertama adaptif terhadap parameter suatu fungsi aktivasi. Output dari tiap-tiap neuron adalah derajaat keanggotaan yang diberikan oleh fungsi keanggotaan input yaitu $\mu_{A_{11}}\left(Z_{(t-1)}\right), \mu_{A_{21}}\left(Z_{(t-1)}\right)$, $\mu_{A_{12}}\left(Z_{(t-2)}\right), \mu_{A_{22}}\left(Z_{(t-2)}\right)$.

2. Lapisan 2 (Operasi logika fuzzy)

Setiap titik pada lapisan-2 merupakan titik tetap yang outputnya merupakan perkalian dari derajat keanggotaan signal yang masuk. Secara umum menggunakan operasi fuzzy AND. Output setiap titik menyatakan firing strength dari aturan ke-i.

$w_{i}=\prod_{q=1}^{m} \mu_{A_{i q}}\left(Z_{(t-q)}\right)$

dengan $\mathrm{i}=1,2$ dan $\mathrm{q}=1,2$

3. Lapisan 3 (Normalized Firing Strength)

Setiap titik lapisan ke-3 merupakan titik tetap, yang menghitung rasio firing strength aturan ke-i relatif terhadap jumlahan firing strength semua aturan yaitu:

$\bar{w}_{i}=\frac{w_{i}}{\sum_{i=1}^{2} w_{i}} ; \mathrm{i}=1,2$ 
Hasilnya merupakan normalized firing strength.

4. Lapisan 4 (Defuzzifikasi)

Setiap titik lapisan ke-4 merupakan titik adaptif. Output setiap titiknya adalah

$\bar{w}_{i} Z_{t}^{(i)}=p_{i 1} Z_{t-1}+p_{i 2} Z_{t-2}+p_{i 0}$; dengan $\mathrm{i}=1,2$

5. Lapisan 5 (Perhitungan output)

Output dari lapisan kelima merupakan output keseluruhan jaringan ANFIS. Output dari lapisan kelima adalah jumlahan dari output lapisan ke empat.

$Z_{t}=\bar{w}_{1}\left(p_{11} Z_{t-1}+p_{12} Z_{t-2}+p_{10}\right)+\bar{w}_{2}\left(p_{21} Z_{t-1}+p_{22} Z_{t-2}+p_{20}\right)$

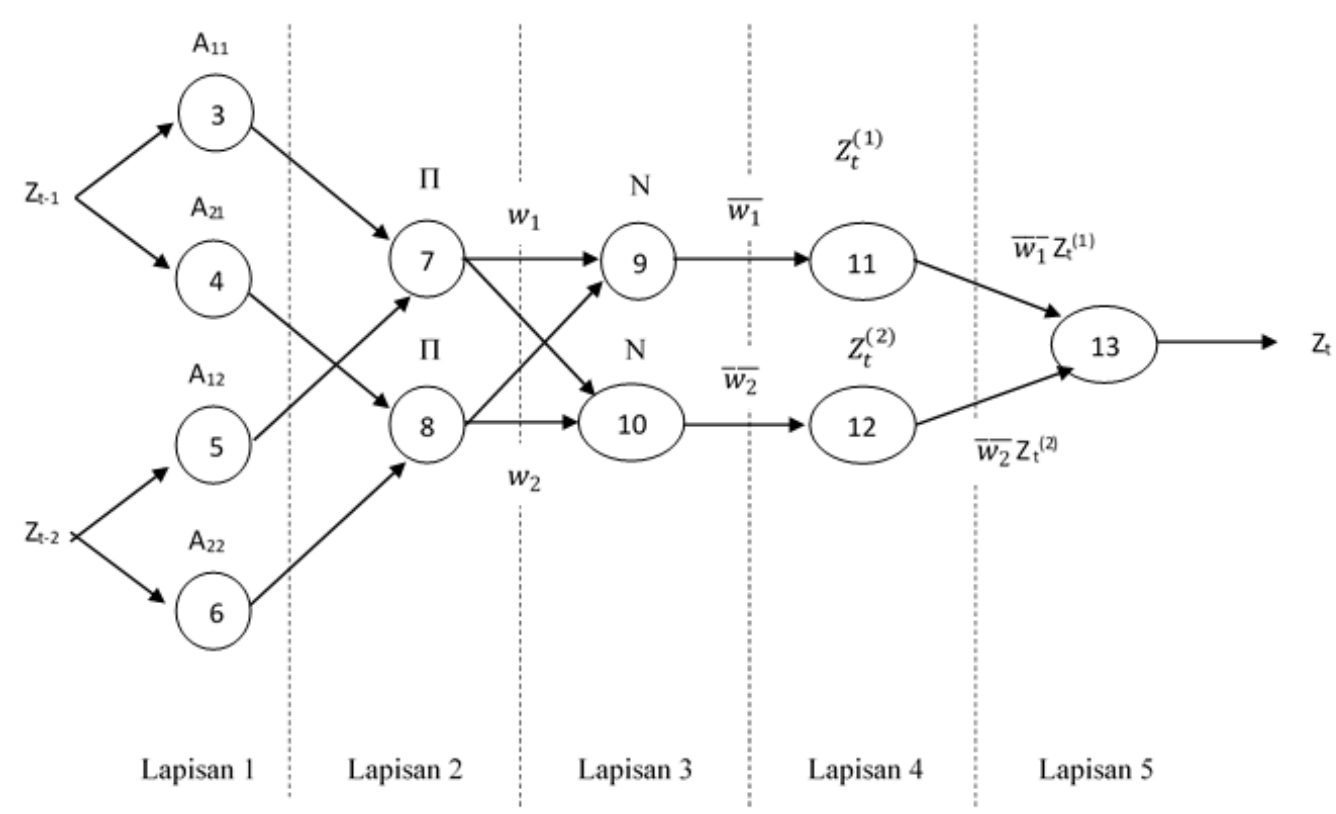

Gambar 1. Contoh Arsitektur ANFIS dengan 2 Input dan 2 Aturan

\subsection{Algoritma Pembelajaran}

Menurut Jang (1997) ANFIS dalam kerjanya mempergunakan algoritma belajar hybrid yaitu menggabungkan metode Least-Squares Estimator (LSE) dan Eror Back-Propagation $(E B P)$. Terdapat dua langkah dalam pelatihan hybrid yaitu langkah maju (forward) dan mundur (backward). Pada langkah maju (forward), parameter premis tetap, input jaringan akan merambat maju sampai pada lapisan keempat, dimana parameter konsekuen $\left(p_{i 1}, p_{i 2}, p_{10}, \ldots, p_{i m}\right)$ akan diidentifikasi dengan menggunakan metode least square estimator (LSE). Sedangkan, pada langkah mundur error sinyal antara keluaran yang diinginkan dengan keluaran aktual, akan merambat mundur dan parameter premis (c dan $\sigma$ ) akan diperbaiki dengan metode gradient-descent .

\subsection{Lagrange Multiplier Test untuk Penambahan Variabel}

Menurut Tarno et al (2018) secara umum, jika diberikan sebanyak $\mathrm{m}$ variabel input $\mathrm{Z}_{\mathrm{t}-1}$, $\mathrm{Z}_{\mathrm{t}-2, \ldots,} \mathrm{Z}_{\mathrm{t}-\mathrm{m}}$ dengan banyaknya jumlah keanggotaan adalah $\mathrm{i}$, maka restricted model ANFIS untuk kasus autoregressive adalah:

$\mathrm{Z}_{\mathrm{t}}=\sum_{i=1}^{C} \sum_{q=1}^{m} p_{i q}\left(\bar{w}_{i} Z_{t-q}\right)+\sum_{i=1}^{C} p_{i 0} \bar{w}_{1}+\varepsilon_{t}$

Unrestricted model ANFIS untuk kasus penambahan satu input adalah

$\mathrm{Z}_{\mathrm{t}}=\sum_{i=1}^{C} \sum_{q=1}^{m+1} p_{i q}\left(\bar{w}_{i} Z_{t-q}\right)+\sum_{i=1}^{C} p_{i 0} \bar{w}_{i}+v_{t}$ berikut:

Pengujian penambahan satu variabel input dapat dirumuskan dengan hipotesis sebagai

$H_{0}: p_{1(m+1)}=p_{2(m+1)}=\cdots=p_{C(m+1)}=0$ atau penambahan input tidak dapat diterima 
$H_{1}=p_{i(m+1)} \neq 0 ; \mathrm{i}=1,2, \ldots, \mathrm{C}$ atau penambahan input dapat diterima

Adapun prosedure LM test menurut Gujarati (2003) adalah sebagai berikut:

1. Estimasi parameter restricted model dan dapatkan nilai residual $\varepsilon_{t}$

2. Mengestimasi parameter regresi antara $\varepsilon_{t}$ dengan variabel lag input dan satu lag input tambahan dengan model sebagai berikut:

$$
\varepsilon_{t}=\sum_{i=1}^{C} \sum_{q=1}^{m+1} p_{i q}\left(\bar{w}_{i} Z_{t-q}\right)+\sum_{i=1}^{C} p_{i 0} \bar{w}_{i}+v_{1}
$$

dimana, $\mathrm{v}_{1}$ merupakan nilai error. Kemudian menghitung nilai R-Square dari persamaan 8

3. Untuk ukuran sampel besar, Engle dalam Gujarati (2003) telah menunjukkan bahwa LM hitung yaitu hasil kali n (ukuran sampel) dan R-Square dari persamaan 8 mengikuti distribusi Chi-square dengan df merupakan jumlah penambahan parameter, sehingga dapat ditulis dalam persamaan sebagai berikut:

$\mathrm{LM}$ hitung $=\mathrm{n} R^{2} \sim \chi_{(\alpha, j u m l a h}^{2}$ penambahan parameter $)$

4. $\mathrm{H}_{0}$ ditolak jika nilai LM hitung yang diperoleh dari persamaan 9 melebihi kritis nilai Chisquare pada tingkat signifikansi yang dipilih, sehingga variabel tambahan dapat diterima.

\section{METODELOGI PENELITIAN}

\subsection{Sumber Data dan Variabel Penelitian}

Data yang digunakan merupakan data simulasi dan data studi kasus. Data simulasi merupakan data hasil bangkitan menggunakan program Matlab yang digunakan sebagai validasi metode LM Test. Terdapat dua karakteristik data yang dibangkitkan yaitu data ARIMA $(2,0,0)$ dan data ARIMA $(2,1,0)$. Sedangkan untuk data studi kasus yang digunakan merupakan data bulanan harga beras kualitas rendah pada penggilingan di Indonesia dari bulan Januari 2013 hingga Februari 2019 yang diperoleh dari Website Badan Pusat Statistik Indonesia. (www.bps.go.id).

\subsection{Tahapan Analisis Data} berikut :

Prosedur pemilihan input model ANFIS berbasis Lagrange Multiplier Test adalah sebagai

1. Membagi data menjadi data insample dan outsample

2. Pemilihan Input dengan Lagrange Multiplier Test

a. Menyiapkan data insample

b. Identifikasi calon variabel lag input, untuk memperoleh susunan calon variabel lag input yang memiliki nilai autokorelasi parsial terbesar hingga terkecil $\left(Z_{t}^{(1)}, Z_{t}^{(2)}, \ldots, Z_{t}^{(r)}\right)$.

c. Pemilihan Variabel lag input

Dengan menggunakan konsep kesederhanaan model maka jumlah keanggotaan minimum yang digunakan untuk pemilihan variabel lag input adalah 2. Langkah untuk melakukan uji lagrange multiplier adalah sebagai berikut:

i. Memilih variabel lag input pertama yaitu $Z_{t}^{(1)}$

ii. Mengestimasi parameter pada restricted model ANFIS dengan variabel output $Z_{t}$ dan variabel lag input yaitu $Z_{t}^{(1)}$

$$
Z_{t}=\bar{w}_{1}\left(p_{11} Z_{t}^{1}+p_{10}\right)+\bar{w}_{2}\left(p_{21} Z_{t}^{1}+p_{20}\right)+\varepsilon_{\mathrm{t}}
$$

iii. Menghitung nilai estimasi residual $\left(\varepsilon_{\mathrm{t}}\right)$ dari restricted model

iv. Memilih calon variabel lag input tambahan yaitu calon variabel lag input terbesar kedua $\left(\mathrm{Z}_{\mathrm{t}}^{(2)}\right)$

v. Membentuk unrestricted model ANFIS untuk penambahan satu variabel lag input $Z_{t}=\bar{w}_{1}\left(p_{11} Z_{t}{ }^{1}+p_{12} Z_{t}{ }^{2}+p_{10}\right)+\bar{w}_{2}\left(p_{21} Z_{t}{ }^{1}+p_{22} Z_{t}{ }^{2}+p_{20}\right)+v_{\mathrm{t}}$

vi. Mengitung nilai R-Square $\left(R_{\varepsilon}^{2}\right)$ dari regresi antara nilai estimasi residual $\left(\varepsilon_{\mathrm{t}}\right)$ dan regresor unrestricted model ANFIS untuk penambahan satu variabel lag input 
vii. Menentukan kesimpulan dari uji hipotesis

Jika nilai LM Hitung $=\mathrm{n} * R_{\varepsilon}^{2}>\chi_{(\alpha, d f)}^{2}$, maka $H_{0}$ ditolak yang berarti bahwa calon variabel lag input tambahan dapat dijadikan input. Dan dilanjutkan untuk calon variabel lag input tambahan yang lain sehingga tidak ada calon variabel lag tambahan yang dapat dijadikan input lagi ( $\mathrm{H}_{0}$ diterima).

d. Pemilihan Jumlah keanggotaan

i. Menghitung nilai MAPE model ANFIS dari variabel lag input terpilih dengan jumlah keanggotaan 2

ii. Menghitung nilai MAPE model ANFIS dari variabel lag input terpilih dengan jumlah keanggotaan 3

iii. Menentukan jumlah keanggotaan optimal yaitu yang menghasilkan nilai MAPE terkecil

\section{Peramalan ANFIS}

Langkah-langkah dalam peramalan ANFIS adalah sebagai berikut:

a. Menyiapkan data insample dan outsample

b. Menentukan variabel output, variabel lag input dan banyaknya keanggotaan berdasarkan hasil dari Lagrange Multiplier Test

c. Menentukan fungsi keanggotaan yang akan digunakan yakni Gauss

d. Membagi input data yang bernilai crisp menjadi linguistik sesuai banyaknya kelompok dengan menggunakan Fuzzy Cluster Mean.

e. Menentukan banyaknya iterasi (epoch) yang diinginkan

f. Menjalankan pelatihan parameter fuzzy inference system dari data insample yakni fuzzifikasi, operasi logika fuzzy, pengaktifan derajat normalisasi dan defuzzifikasi

g. Meramalkan data dari model data insampel

h. Menghitung ketepatan model dengan MAPE outsampel

i. Interpretasi

\section{HASIL DAN PEMBAHASAN}

\subsection{Penerapan pada Data Simulasi}

\subsubsection{Pemilihan Input pada Data Simulasi}

Autokorelasi parsial menunjukkan tingkat keeratan antara $\mathrm{Z}_{\mathrm{t}}$ dengan masing-masing calon variabel lag input. Variabel lag input yang memiliki nilai autokorelasi parsial tertinggi merupakan input pertama dalam ANFIS.

Tabel 1. Nilai Autokorelasi Parsial pada Data Simulasi

\begin{tabular}{ccc}
\hline Data & Lag & Nilai Autokorelasi Parsial \\
\hline \multirow{3}{*}{ ARIMA $(2,0,0)$} & $Z_{t-1}$ & 0,8368 \\
& $Z_{t-2}$ & 0,3163 \\
& $Z_{t-3}$ & 0,0315 \\
\hline \multirow{2}{*}{ ARIMA $(2,1,0)$} & $Z_{t-1}$ & 0,9920 \\
& $Z_{t-2}$ & 0,6122 \\
& $Z_{t-3}$ & 0,3103 \\
& $Z_{t-4}$ & 0,0815 \\
\hline
\end{tabular}

Berdasarkan Tabel 1 terlihat bahwa input pertama ANFIS pada Data ARIMA $(2,0,0)$ adalah $Z_{t-1}$ sedangkan, pada Data ARIMA $(2,1,0)$ yang menjadi input pertama ANFIS adalah $Z_{t-1}$.

Pemilihan input ANFIS selanjutnya dilakukan dengan lagrange multiplier test untuk penambahan satu variabel input. Variabel input yang diuji dimulai dari variabel input yang memiliki nilai autokorelasi terbesar kedua dan seterusnya. Lagrange Multiplier Test berhenti ketika $H_{0}$ diterima. 
Tabel 2. Ringkasan Hasil LM Test pada Data ARIMA $(2,0,0)$ dan ARIMA $(2,1,0)$

\begin{tabular}{cccccc}
\hline Data & Input & $\begin{array}{c}\text { Input } \\
\text { Tambahan }\end{array}$ & LM Hitung & LM Tabel & Keputusan \\
\hline ARIMA & $Z_{t-1}$ & $Z_{t-2}$ & 10,1911 & 5,9915 & $H_{0}$ ditolak \\
$(2,0,0)$ & $Z_{t-1}$ dan $Z_{t-2}$ & $Z_{t-3}$ & 0,8704 & 5,9915 & $H_{0}$ diterima \\
\hline \multirow{3}{*}{ ARIMA } & $Z_{t-1}$ & $Z_{t-2}$ & 39,1165 & 5,9915 & $H_{0}$ ditolak \\
$(2,1,0)$ & $Z_{t-1}, Z_{t-2}$ & $Z_{t-3}$ & 11,4578 & 5,9915 & $H_{0}$ ditolak \\
& dan $Z_{t-3}$ & $Z_{t-4}$ & 0,7749 & 5,9915 & $H_{0}$ diterima \\
\hline
\end{tabular}

Berdasarkan Tabel 2 terlihat bahwa input ANFIS terpilih menggunakan LM Test pada Data ARIMA $(2,0,0)$ adalah $Z_{t-1}$ dan $Z_{t-2}$. Sedangkan pada Data ARIMA $(2,1,0)$ adalah $Z_{t-1}, Z_{t-2}$ dan $Z_{t-3}$.

Banyaknya keanggotaan pada ANFIS dipilih berdasarkan nilai MAPE insample terkecil dari pelatihan ANFIS dengan banyak keanggotaan 2 dan 3.

Tabel 3. Ringkasan Nilai MAPE insample dari Pelatihan ANFIS pada Data ARIMA $(2,0,0)$ dan Data ARIMA $(2,1,0)$

\begin{tabular}{ccc}
\hline Data & $\begin{array}{c}\text { Banyak } \\
\text { Keanggotaan }\end{array}$ & $\begin{array}{c}\text { MAPE } \\
\text { Insample }\end{array}$ \\
\hline ARIMA (2,0,0) & 2 & 3,1108 \\
& 3 & 3,1579 \\
ARIMA $(2,1,0)$ & 2 & 9,6796 \\
& 3 & 12,3887 \\
\hline
\end{tabular}

Berdasarkan Tabel 3,pada Data ARIMA $(2,0,0)$ dan ARIMA $(2,1,0)$ banyaknya keanggotaan yang terpilih adalah 2 .

\subsubsection{Pemodelan pada Data Simulasi}

Pada Data ARIMA $(2,0,0)$, dengan input $Z_{t-1}$ dan $Z_{t-2}$ serta banyak keanggotaan 2 maka terbentuk 2 aturan sebagai berikut:

If $Z_{t-1}$ is $A_{11}$ and $Z_{t-2}$ is $A_{12}$ then $Z_{t}^{(1)}=p_{11} Z_{t-1}+p_{12} Z_{t-2}+p_{10}$;

If $Z_{t-1}$ is $A_{21}$ and $Z_{t-2}$ is $A_{22}$ then $Z_{t}^{(2)}=p_{21} Z_{t-1}+p_{22} Z_{t-2}+p_{20}$;

Sehingga diperoleh model ANFIS Data ARIMA $(2,0,0)$ sebagai berikut:

$Z_{\mathrm{t}}=-0,1998 Z_{\mathrm{t}-1} \bar{w}_{1}-4,2000 Z_{\mathrm{t}-2} \bar{w}_{1}+148,1000 \bar{w}_{1}+0,5629 Z_{\mathrm{t}-1} \bar{w}_{2}+$

$0,3077 Z_{\mathrm{t}-2} \bar{w}_{2}+3,0930 \bar{w}_{2}$

dengan,

$$
\begin{aligned}
& \bar{w}_{i}=\frac{w_{i}}{\sum w_{i}} \text { untuk } \mathrm{i}=1,2 \\
& w_{1}=\exp \left\{-\frac{1}{2}\left(\left(\frac{Z_{(t-1)}-27,0200}{0,6756}\right)^{2}+\left(\frac{Z_{(t-2)}-27,5400}{0,353}\right)^{2}\right)\right\}, \\
& w_{2}=\exp \left\{-\frac{1}{2}\left(\left(\frac{z_{(t-1)}-23,6000}{2,6990}\right)^{2}+\left(\frac{Z_{(t-2)}-23,6400}{2,7540}\right)^{2}\right)\right\}
\end{aligned}
$$

Pada Data ARIMA $(2,1,0)$, dengan input $Z_{t-1}, Z_{t-2}$ dan $Z_{t-3}$ serta banyak keanggotaan 2 maka terbentuk 2 aturan sebagai berikut:

If $Z_{t-1}$ is $A_{11}$ and $Z_{t-2}$ is $A_{12}$ and $Z_{t-3}$ is $A_{13}$ then $Z_{t}^{(1)}=p_{11} Z_{t-1}+p_{12} Z_{t-2}+$ $p_{13} Z_{t-3}+p_{10}$

If $Z_{t-1}$ is $A_{21}$ and $Z_{t-2}$ is $A_{22}$ and $Z_{t-3}$ is $A_{23}$ then $Z_{t}^{(2)}=p_{21} Z_{t-1}+p_{22} Z_{t-2}+$ $p_{23} Z_{t-3}+p_{20}$

Model ANFIS pada Data ARIMA $(2,1,0)$ adalah sebagai berikut: 
$\mathrm{Z}_{\mathrm{t}}=1,3560 \bar{w}_{1} \mathrm{Z}_{\mathrm{t}-1}-0,0747 \bar{w}_{1} \mathrm{Z}_{\mathrm{t}-2}-0,3163 \bar{w}_{1} \mathrm{Z}_{\mathrm{t}-3}-0,0983 \bar{w}_{2}+1,2110 \bar{w}_{2} \mathrm{Z}_{\mathrm{t}-1}+$ $0,0020 \bar{w}_{2} \mathrm{Z}_{\mathrm{t}-2}-0,4768 \bar{w}_{2} \mathrm{Z}_{\mathrm{t}-3}+0,1215 \bar{w}_{2}$

dengan,

$\bar{w}_{i}=\frac{w_{i}}{\sum w_{i}}$ untuk $\mathrm{i}=1,2$

$w_{1}=\exp \left\{-\frac{1}{2}\left(\left(\frac{Z_{(t-1)}+2,5880}{1,8460}\right)^{2}+\left(\frac{Z_{(t-2)}+2,5440}{1,8800}\right)^{2}+\left(\frac{Z_{(t-3)}+2,5000}{1,9690}\right)^{2}\right)\right\}$,

$w_{2}=\exp \left\{-\frac{1}{2}\left(\left(\frac{Z_{(t-1)}-0,6676}{0,6395}\right)^{2}+\left(\frac{Z_{(t-2)}-0,7086}{0,3040}\right)^{2}+\left(\frac{Z_{(t-3)}-0,5379}{1,8460}\right)^{2}\right)\right\}$

\subsubsection{Peramalan pada Data Simulasi}

Peramalan ANFIS dengan input optimum pada Data ARIMA $(2,0,0)$ menghasilkan nilai MAPE outsample 5,6785\%. Sedangkan, pada Data ARIMA $(2,1,0)$ menghasilkan MAPE outsample 9,4547\%.Model ANFIS yang terbentuk memiliki kemampuan peramalan yang sangat baik.

\subsection{Penerapan pada Data Studi Kasus}

\subsubsection{Pemilihan Input pada Data Studi Kasus}

Autokorelasi parsial menunjukkan tingkat keeratan antara Zt dengan masing-masing calon variabel lag input. Variabel lag input yang memiliki nilai autokorelasi parsial tertinggi merupakan input pertama dalam ANFIS.

Tabel 4. Nilai Autokorelasi Parsial

\begin{tabular}{ccc}
\hline Data & Lag & Nilai Autokorelasi Parsial \\
\hline \multirow{3}{*}{ Harga Beras } & $Z_{t-1}$ & 0,9524 \\
& $Z_{t-2}$ & 0,5169 \\
& $Z_{t-3}$ & 0,1156 \\
\hline
\end{tabular}

Berdasarkan Tabel 4 terlihat bahwa input pertama ANFIS pada Data studi kasus adalah $Z_{t-1}$.

Pemilihan input ANFIS selanjutnya dilakukan dengan lagrange multiplier test untuk penambahan satu variabel input. Variabel input yang diuji dimulai dari variabel input yang memiliki nilai autokorelasi terbesar kedua dan seterusnya. Lagrange Multiplier Test berhenti ketika $H_{0}$ diterima.

Tabel 5. Ringkasan Hasil LM Test pada Data Studi Kasus

\begin{tabular}{cccccc}
\hline Data & Input & $\begin{array}{c}\text { Input } \\
\text { Tambahan }\end{array}$ & LM Hitung & LM Tabel & Keputusan \\
\hline Harga & $Z_{t-1}$ & $Z_{t-2}$ & 17,5434 & 5,9915 & $H_{0}$ ditolak \\
Beras & $Z_{t-1}$ dan $Z_{t-2}$ & $Z_{t-3}$ & 0,4970 & 5,9915 & $H_{0}$ diterima \\
\hline
\end{tabular}

Berdasarkan Tabel 5 terlihat bahwa input ANFIS terpilih menggunakan LM Test pada Data Harga Beras adalah $Z_{t-1}$ dan $Z_{t-2}$.

Banyaknya keanggotaan pada ANFIS dipilih berdasarkan nilai MAPE insample terkecil dari pelatihan ANFIS dengan banyak keanggotaan 2 dan 3.

Tabel 6. Ringkasan Nilai MAPE insample dari Pelatihan ANFIS pada Data Studi Kasus

\begin{tabular}{ccc}
\hline Data & $\begin{array}{c}\text { Banyak } \\
\text { Keanggotaan }\end{array}$ & $\begin{array}{c}\text { MAPE } \\
\text { Insample }\end{array}$ \\
\hline \multirow{2}{*}{ Harga Beras } & 2 & 1,6175 \\
& 3 & 1,6264 \\
\hline
\end{tabular}

Berdasarkan Tabel 6,pada Data studi kasus harga beras banyaknya keanggotaan yang terpilih adalah 2. 


\subsubsection{Pemodelan pada Data Studi Kasus}

Pada data harga beras dengan input $Z_{t-1}$ dan $Z_{t-2}$, serta banyak keanggotaan 2 maka terbentuk 2 aturan sebagai berikut:

If $Z_{t-1}$ is $A_{11}$ and $Z_{t-2}$ is $A_{12}$ then $Z_{t}^{(1)}=p_{11} Z_{t-1}+p_{12} Z_{t-2}+p_{10}$;

If $Z_{t-1}$ is $A_{21}$ and $Z_{t-2}$ is $A_{22}$ then $Z_{t}^{(2)}=p_{21} Z_{t-1}+p_{22} Z_{t-2}+p_{20}$;

Pada lapisan 1 dalam arsitektur ANFIS terdapat 4 kelompok nilai awal parameter premis, dengan nilai-nilai tersebut akan digunakan untuk proses pembelajaran. Setelah diperoleh nilai awal parameter premis, maka output yang dihasilkan pada lapisan pertama adalah derajat keanggotaan setiap input yaitu $\mu_{A_{11}}\left(Z_{(t-1)}\right), \mu_{A_{21}}\left(Z_{(t-1)}\right), \mu_{A_{12}}\left(Z_{(t-2)}\right), \mu_{A_{22}}\left(Z_{(t-2)}\right)$. Derajat keanggotaan tersebut digunakan sebagai input pada lapisan 2 yang menghasilkan derajat pengaktifan tiap aturan. Pada ANFIS optimal tersebut memiliki 2 aturan, maka output lapisan 2 berupa $w_{1}$ dan $w_{2}$. Output lapisan 2 digunakan sebagai input pada lapisan 3 yang akan dilakukan normalisasi pada derajat pengaktifan tersebut, maka output lapisan 3 berupa $\bar{w}_{1}$ dan $\bar{w}_{2}$. Output lapisan ini, digunakan sebagai input pada lapisan 4, dengan menggunakan Least Square Estimator Rekursif, pada lapisan 4 diperoleh parameter konsekuen dalam bentuk linear untuk setiap aturan yaitu:

$$
\begin{aligned}
& Z_{t}^{(1)}=1,2450 \bar{w}_{1} Z_{t-1}-0,6096 \bar{w}_{1} Z_{t-2}+3168 \bar{w}_{1} ; \\
& Z_{t}^{(2)}=1,4990 \bar{w}_{2} Z_{t-1}-0,5847 \bar{w}_{2} Z_{t-2}+670,4000 \bar{w}_{2} ;
\end{aligned}
$$
berikut:

Pada lapisan 5, output dari lapisan 4 dijumlahkan sehingga diperoleh model sebagai

$$
\begin{aligned}
& \quad \mathrm{Z}_{\mathrm{t}}=1,2450 \bar{w}_{1} Z_{t-1}-0,6096 \bar{w}_{1} Z_{t-2}+3168 \bar{w}_{1}+1,4990 \bar{w}_{2} Z_{t-1}- \\
& 0,5847 \bar{w}_{2} Z_{t-2}+670,4000 \bar{w}_{2} \\
& \text { dengan, } \\
& \bar{w}_{i}=\frac{w_{i}}{\sum w_{i}} \text { untuk i=1,2 } \\
& w_{1}=\exp \left\{-\frac{1}{2}\left(\left(\frac{z_{(t-1)}-8683}{650,8000}\right)^{2}+\left(\frac{Z_{(t-2)}-8647}{650,7000}\right)^{2}\right)\right\}, \\
& w_{2}=\exp \left\{-\frac{1}{2}\left(\left(\frac{z_{(t-1)}-7514}{580,8000}\right)^{2}+\left(\frac{z_{(t-2)}-7504}{580,7000}\right)^{2}\right)\right\}
\end{aligned}
$$

\subsubsection{Peramalan}

Peramalan ANFIS dengan input optimum yang terpilih yaitu $Z_{t-1}$ dan $Z_{t-2}$ serta banyaknya keanggotaan 2 menghasilkan MAPE Outsample 6,4018\% sehingga model ANFIS yang terbentuk memiliki kemampuan peramalan yang sangat baik. Hasil peramalan untuk 5 bulan berikutnya disajikan dalam Tabel 7:

Tabel 7. Hasil Peramalan 5 Periode ke Depan

\begin{tabular}{lc}
\hline Tanggal & Kurs Rupiah \\
\hline Maret 2019 & 8665,1598 \\
April 2019 & 8667,2174 \\
Mei 2019 & 8673,0753 \\
Juni 2019 & 8679,1786 \\
Juli 2019 & 8683,2888 \\
\hline
\end{tabular}

\subsection{GUI Pemilihan Input Berbasis Lagrange Multiplier Test}

GUI pemilihan input berbasis lagrange multipliet test terdiri dari 4 layar yaitu:

1. Layar utama yang berisi informasi mengenai judul GUI dan beberapa tab untuk menjalankan GUI pemilihan input berbasis LM Test. 


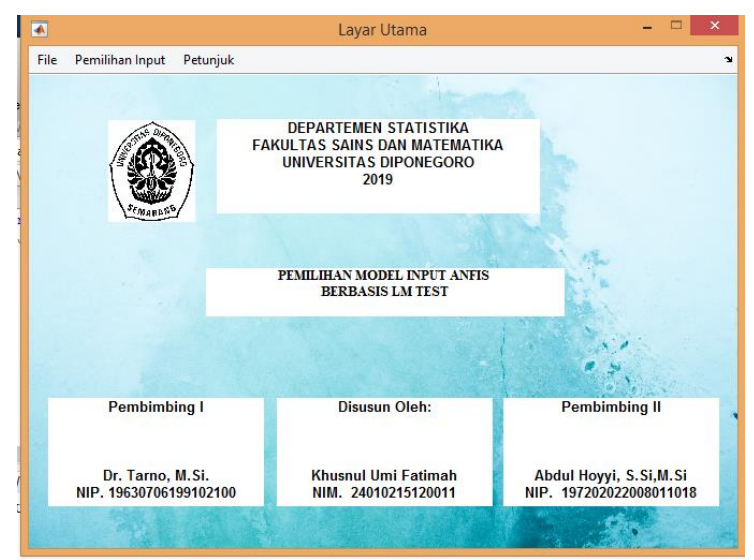

Gambar 1. Tampilan Layar Utama

2. Layar Identifikasi variabel digunakan untuk menghitung nilai autokorelasi parsial sebagai preprocessing dalam pemilihan input berbasis LM Test

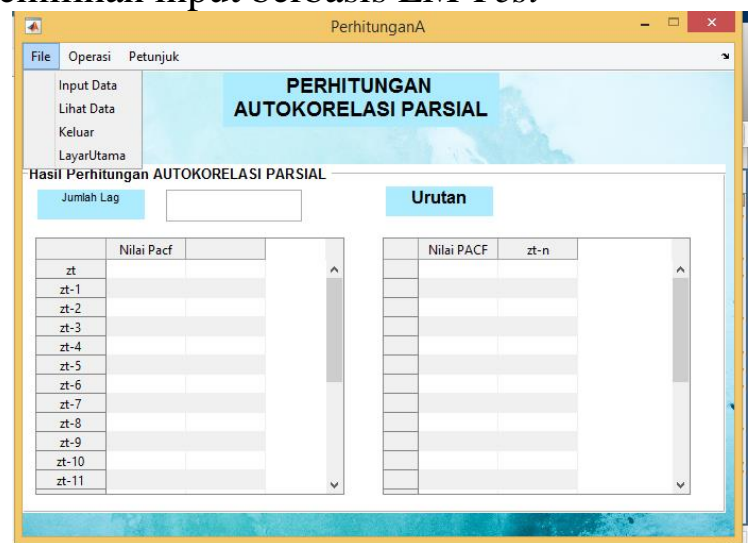

Gambar 2. Tampilan Layar Identifikasi Variabel

3. Layar pemilihan input digunakan untuk uji hipotesis penambahan satu variabel input pada model ANFIS

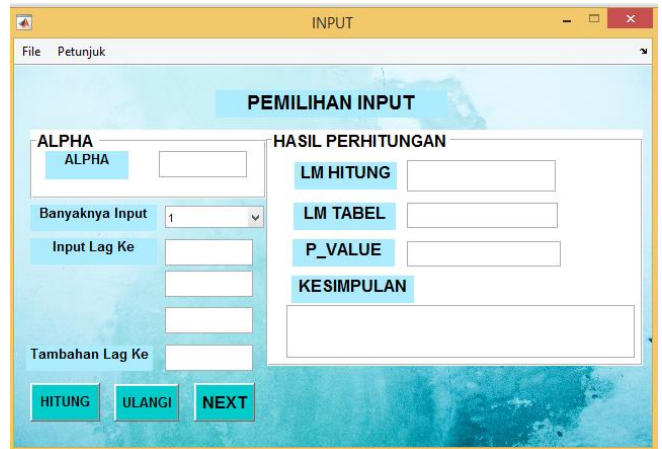

Gambar 3. Tampilan Layar Pemilihan Input

4. Layar pemilihan banyaknya keanggotaan digunakan untuk memilih banyaknya keanggotaan manghasilkan nilai MAPE terkecil. 


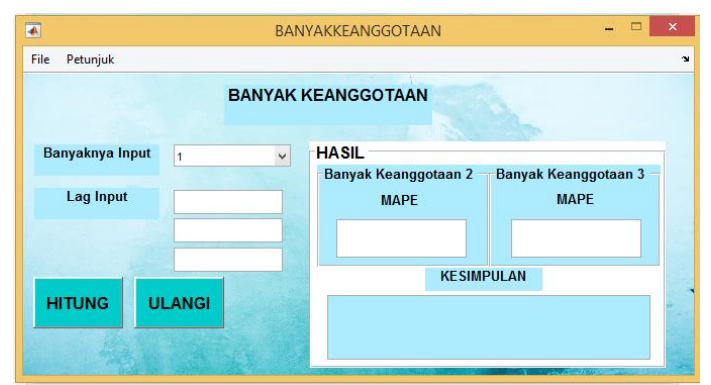

Gambar 4. Tampilan Layar Banyaknya Keanggotaan

\section{KESIMPULAN} berikut:

Berdasarkan hasil dan pembahasan dapat diperoleh beberapa kesimpulan sebagai

1. Pemilihan input ANFIS yang optimal berbasis LM Test terdiri dari dua prosedur yaitu identifikasi variabel lag input dan uji hipotesis dengan LM Test untuk penambahan satu variabel input. Berdasarkan hasil input optimal yang terpilih dan nilai MAPE outsample serta insample yang bernilai kurang dari $10 \%$ pada data simulasi ARIMA $(2,0,0)$ dan ARIMA $(2,1,0)$ maka pemilihan input ANFIS berbasi LM Test dapat bekerja dengan baik.

2. GUI Matlab pemilihan input model ANFIS berbasis Lagrange Multiplier Test dibuat melalui dua tahap yaitu merancang desain dan menulis perintah fungsi callback untuk menjalankan perintah.

3. Model ANFIS terbaik untuk data bulanan harga beras kualitas rendah pada penggilingan di Indonesia dengan input optimal yaitu $\mathrm{Z}_{\mathrm{t}-1}, \mathrm{Z}_{\mathrm{t}-2}$ dan banyaknya keanggotaan 2 adalah:

$Z_{\mathrm{t}}=1,2450 \bar{w}_{1} Z_{t-1}-0,6096 \bar{w}_{1} Z_{t-2}+3168 \bar{w}_{1}+1,4990 \bar{w}_{2} Z_{t-1}-0,5847 \bar{w}_{2} Z_{t-2}+$ $670,4000 \bar{w}_{2}$

dengan,

$\bar{w}_{i}=\frac{w_{i}}{\sum w_{i}}$ untuk $\mathrm{i}=1,2$

$w_{1}=\exp \left\{-\frac{1}{2}\left(\left(\frac{z_{(t-1)}-8683}{650,8000}\right)^{2}+\left(\frac{z_{(t-2)}-8647}{650,7000}\right)^{2}\right)\right\}$

$w_{2}=\exp \left\{-\frac{1}{2}\left(\left(\frac{Z_{(t-1)}-7514}{580,8000}\right)^{2}+\left(\frac{Z_{(t-2)}-7504}{580,7000}\right)^{2}\right)\right\}$

4. Hasil peramalan dari model ANFIS yang terpilih menghasilkan MAPE sebesar 6,4018\%, sehingga model ini mempunyai kemampuan peramalan yang sangat baik.

\section{DAFTAR PUSTAKA}

[BPS].Badan Pusat Statistik.2019. Rata-Rata Harga Beras Bulanan di Tingkat Penggilingan Menurut Kualitas, 2013-2019 (Rupiah/Kg). https://www.bps.go.id/linkTableDinamis/view/id/1102. Diakses: 15 Maret 2019.

Andalita, I., dan Irhamah. 2015. Peramalan Jumlah Penumpang Kereta Api Kelas Ekonomi Kertajaya Menggunakan ARIMA dan ANFIS. Jurnal Sains dan Seni ITS Vol. 4, No.2, 2337-3520.

Chang, J. R., Wei, L. Y., dan Cheng, C. H. 2011. A Hybrid Anfis Model Based on AR and Volatility for TAIEX Forecasting. Applied Soft Computing 11, 1388-1395.

Chang, P. C., Wang, Y. W., dan Liu, C. H. 2007. The Development of A Weighted Evolving Fuzzy Neural Network for PCB Sales Forecasting . Expert Systems with Applications, 32(1), 86-96.

Fatkhurrozi, B., Muslim, M., dan Didik, R. 2012. Penggunaan Artificial Neuro Fuzzy Inference Sistem (ANFIS) dalam Penentuan Status Aktivitas Gunung Merapi. Jurnal EECCIS, Vol. 6(2): 113-118. 
Gujarati , D. N. 2003. Basic Econometric. New York: Gary Burke. Hunt, B. R., Lipsman , R. L., dan Rosenb, J. M. 2001. A Guide to MATLAB for Beginners and Experienced Users. New York: Cambridge University Press.

Jang, J., Sun, C. T., dan Mizutani, E. 1997. Neuro-Fuzzy and Soft Computing: A Computational Approach to Learning and Machine Intelegence. London: Prentice-Hall;Inc.

Permai, S. D., Iriawan, N., dan Irhamah. 2013. Pemodelan Kecepatan Angin Rata-Rata. Statistika, Vol. 1, No. 2.

Tarno, Rusgiyono, A., Warsito, B., Sudarno, dan Ispriyanti, D. 2018. Pemodelan Hybrid ARIMA-ANFIS untuk Data Produksi Tanaman Hortikultural di Jawa Tengah. Media Statistika 11(1), 65-78. 